\title{
TMJ dimensions in three-dimensional virtual models acquired through computed tomography of cone beam as sexual dimorphism
}

Dimensões das ATM em modelos virtuais tridimensionais obtidos por tomografia computadorizada de feixe cônico como determinantes do dimorfismo sexual

Cristiano de FRANÇA ${ }^{1}$, Helena Midori CUNHA ${ }^{1}$, Ana Amélia BARBIERI ${ }^{2}$, Afonso Celso Souza ASSIS ${ }^{1}$, Luís Roberto MANHÃES JÚNIOR $^{1}$, Sérgio Lúcio Pereira de Castro LOPES ${ }^{1}$

1 - São Paulo State University (Unesp) - Institute of Science and Technology - São José dos Campos - Department of Biosciences and Oral Diagnosis - SP - Brazil.

2 - São Paulo State University (Unesp) - Institute of Science and Technology - São José dos Campos - Department of Social and Pediatric Dentistry - SP - Brazil.

\begin{abstract}
Objective: The objective of this study was to relate the dimensions of the mandibular condyle with sex and age by means of three-dimensional models obtained by cone-beam computed tomography images (CBCT). Material and Methods: 120 CBCT examinations were selected belonging to the archives of the ICTUNESP Clinic of Radiology. They were divided into five age groups, each containing 12 individuals of each sex. Virtual three-dimensional models were then created and two measurements from each mandibular condyle were taken: anteroposterior (AP) and mediolateral (ML). The t-test was used for independent samples to compare the measurements. Results: The AP measurements only of the left side showed a statistical difference between the sexes between 31 to 40 years of age; in the ML measurements, there were statistical differences between the sexes in all age groups on both sides, except in the age group above 60 years. Conclusion: The ML measurements of the mandibular condyles, regardless of side, showed significant statistical differences between sexes and age groups, with a tendency to greater values in males, and may be a determinant factor of sexual dimorphism.
\end{abstract}

\section{KEYWORDS}

X-Ray computed Tomography; Radiology; Sexual characteristics; Forensic anthropology; Forensic dentistry.

\section{RESUIMO}

Objetivo: Este estudo objetivou relacionar as dimensões da cabeça da mandíbula com o sexo e faixa etária por meio de modelos tridimensionais obtidos por imagens de tomografia computadorizada de feixe cônico (TCFC). Material e Métodos: Foram selecionados 120 exames de TCFC pertencentes ao arquivo da Clínica de Radiologia ICT-UNESP, divididos em 04 faixas etárias, cada uma contendo 12 indivíduos de cada sexo então obtidos modelos tridimensionais virtuais e realizadas, duas medidas em cada cabeça da mandíbula: ântero-posterior (AP) e látero medial (LM). Utilizou-se teste t para amostras independentes para comparação das mensurações. Resultados: nas medidas AP apenas no lado esquerdo, entre 31 a 40 anos de idade apresentou diferença estatística entre os sexos; nas medidas LM, houve diferenças estatísticas entre os sexos em todas as faixas etárias em ambos os lados, exceto na faixa etária acima de 60 anos. Conclusão: as medidas LM das cabeças da mandíbula, independente do lado, apresentaram-se com diferenças estatisticamente significantes entre os sexos e faixas etárias, com tendência a maiores valores no sexo masculino, podendo ser um fator determinante de dimorfismo sexual.

\section{PALAVRAS-CHAVE}

Tomografia Computadorizada por Raios X; Radiologia; Caracteres Sexuais; Antropologia Forense; Odontologia Legal. 


\section{INTRODUCTION}

orensic anthropology is a field of - knowledge that broadens the methods of physical anthropology and archeology in a legal context, seeking to establish the identity of the subject through the individualization of characteristics intrinsic to the situation. Forensic dentistry is of great importance in the process of identification, especially when its professionals receive only the cephalic portion of the body for analysis. Several structures, components of the craniofacial skeleton have been used as determinants for estimating the age and sex of individuals, as well as for identifying corpses.

According to the Scientific Working Group for Forensic Anthropology (SWGANTH), the post-mortem process of identification is an integral aspect of the medical-legal death investigation. Thus, forensic anthropologists identify human remains through the evaluation and comparison of information ante- and postmortem.

Sexual dimorphism from the analysis of skeletal remains, as well as the other general parameters of medical-legal identification, is a crucial step in the forensic investigation [1].

The human mandible has been studied for its usefulness in the categorization of human groups, in the description of differences between modern and fossil forms and, particularly, in the determination of patterns of sexual dimorphism. The adult human mandible is a peculiarly robust and durable bone, usually preserved in forensic contexts [2]. In addition, it is a more sexually dimorphic bone when compared to other bones in the human skeleton [3].

Among the various joints of the human skeleton, the temporomandibular joint (TMJ) stands out for its morphofunctional complexity, and is often subject to conditions that could lead to the modification of its bone components, including the mandibular condyle (MC).
The mandibular condyle is the TMJ's mobile component, and its morphology and size may vary between individuals of distinct race, age, and sex.

The cone-beam computed tomography (CBCT) is a method that was first introduced in Italy in 1997, and has been used commercially in the USA since 2001. Its advantages include a lower dose of radiation when compared with fan-beam computed tomography (FBCT), the absence of overlapping images, a high degree of spatial resolution of bone tissues, the possibility of multiplanar reconstructions, precision in the measurements of images, and the possibility of obtaining real distances between important anatomical structures in the maxillofacial complex. These many factors have brought this technique into wide usage.

In addition to the benefits cited, the CBCT is able to generate virtual three-dimensional models (3D models) by means of volume rendering, displayed on the computer screen on which different protocols can be applied for reconstruction in order to emphasize hard and soft tissues, as well as airways in the head and neck region without the need to acquire additional images. These 3D models constitute a reliable reproduction of the patient's tissues, and can even be printed physically in a process called rapid prototyping.

Several softwares are currently used for image reconstruction of CBCT images into 3D models, with many of them having various tools that allow measuring of distances, angles, and even obtaining volumes of regions of interest through the process of segmentation by volume [4-6]. Some studies have used 3D CBCT models to determine measurements such as the distance between the mental foramina and the base of the mandible to determine the age and sex of individuals; however, no studies were found in the literature that utilized virtual 3D models to characterize the dimensions of the mandibular condyle, and their relationship with the sex in a population, so as to contribute to forensic 
identification as a determinant of sexual dimorphism, which justifies the importance of this study. In this context, the objective of the present study has no precedent.

\section{MATERIAL AND METHODS}

This study was approved by the Human Research Ethics Committee of the Institute of Science and Technology of the Universidade Estadual Paulista under protocol CAAE: 52961416.9.0000.0077.

\section{Characterization of the Sample}

The sample was composed of 120 conebeam computed tomography (СВCT) exams, with 60 exams from males and 60 from females. These were divided into five (5) age groups: 18 to 30 years, 31 to 40 years, 41 to 50 years, 51 to 60 years, and finally 60 years or more, with each age group composed of 12 exams. The images were gathered from the archives in the Clinic of Radiology at the School of Dentistry, Institute of Science and Technology of the Universidade Estadual Paulista - Júlio de Mesquita Filho, located in the city of São José dos Campos, state of São Paulo, in the period between September of 2012 and November of 2015.

The CBCT exams selected were obtained from a CT scanner of the brand i-CAT Next Generation (Imaging Sciences, Hatfield, PA, USA) with the same protocol: FOV of $16 \times 13 \mathrm{~cm}$, voxel of $0.25 \mathrm{~mm}$, reaching the bilateral TMJs in their entirety. The images were obtained with all patients in occlusion.

As a criterion for exclusion, subjects were eliminated from the sample exams who had pathologies or alterations on the surface of the mandibular condyle such as eburnization, osteophyte, subchondral cyst, or developmental anomalies such as hypoplasia and hyperplasia, bifid mandibular condyle, fractures, images not including both mandibular condyles completely, poor quality images that made it impossible to visualize the mandibular condyles perfectly, and the presence of any neoplastic processes.

The images were evaluated in a suitable environment with reduced lighting, on a 19- inch LED monitor, by two raters previously trained and experienced in analyzing CBCT images. To minimize the intra-rater error, the measurements were made individually, repeated initially in $20 \%$ of the sample, for agreement between them. The Kappa test was applied for evaluation of inter-rater agreement.

\section{Determining the measurements on the images.}

Each selected examination was exported in the Digital Imaging and Communications in Medicine (DICOM) format to the software OnDemand 3D (Cybermed Inc., Geumcheongu, Seoul, Korea), which provides a virtual 3D model, allowing measurements to be made.

A virtual 3D model was constructed in the multiplanar reconstruction (MPR) window of OnDemand3D, where the software applied the pre-determined bone protocol (Figure 1).

The 3D measuring tool was then selected, which permitted measurements to be taken in the virtual 3D model between distinct points, with the following measurements being taken on each mandibular condyle (bilateral) (Figures 2 and 3$)$ :

a) Distance between the most anterior and the most posterior points (APD).

b) Distance between the lateral and medial poles (MLD).

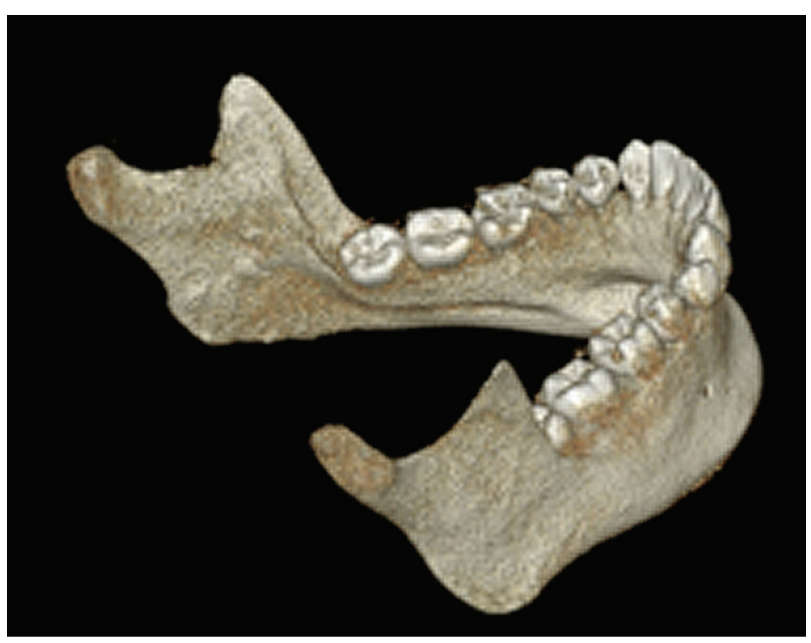

Figure 1 - Three-dimensional model of the mandible in bone protocol, generated in the software OnDemand3D, where the measurements were made. 
The data were tabulated in Microsoft Excel, as grouped within the five age groups, and the t-test was applied to independent samples to analyze any possible statistically significant differences $(\mathrm{p} \leq 0.05)$ between the sexes, in the anteroposterior (AP) and mediolateral (ML) measurements of the mandibular condyles (MC) on the left and right sides, individually.

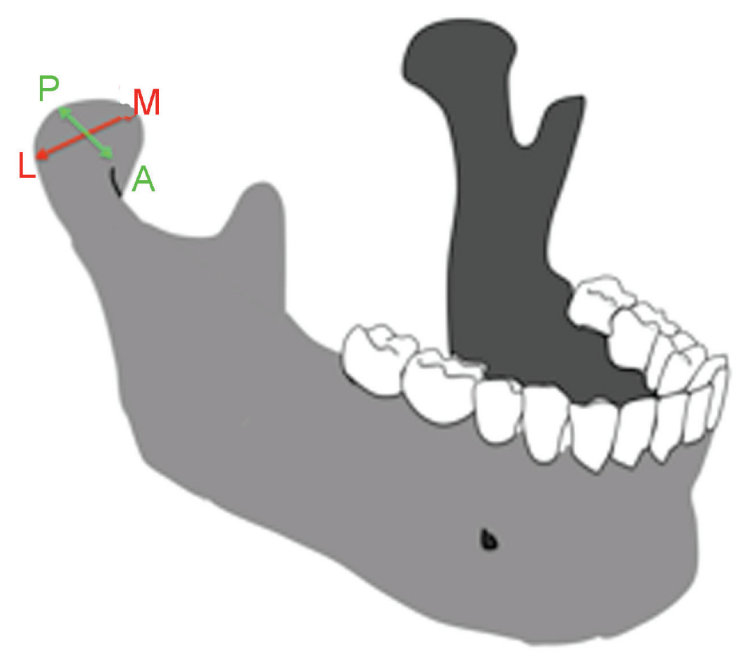

Figure 2 - Scheme showing the measurements to be made on the virtual 3D model.

\section{RESULTS}

The results related to the standard deviation for independent samples are shown in Tables 1 and 2.

Table 1 - Standard Deviation Values present in individual samples in AP and ML measurements on the left and right sides of the mandibular condyles (MC) of male individuals

\begin{tabular}{|c|c|c|c|c|}
\hline Age & & Stand & eviation & \\
\hline \multirow[t]{2}{*}{ Group } & \multicolumn{4}{|c|}{ For Males } \\
\hline & APRight & APLeft & ML Right & MLLeft \\
\hline $18-30$ & 0.94 & 0.91 & 0.97 & 1.18 \\
\hline $31-40$ & 0.85 & 0.92 & 1.99 & 2.44 \\
\hline $41-50$ & 1.33 & 1.21 & 1.42 & 0.89 \\
\hline $51-60$ & 1.19 & 0.75 & 1.80 & 0.81 \\
\hline 60 or + & 1.17 & 0.96 & 1.64 & 1.20 \\
\hline
\end{tabular}

AP: Anteroposterior measurements of the MC; ML: mediolateral measurements of the MC.

${ }^{\star} \mathrm{p} \leq 0.05$ (statistically significant).
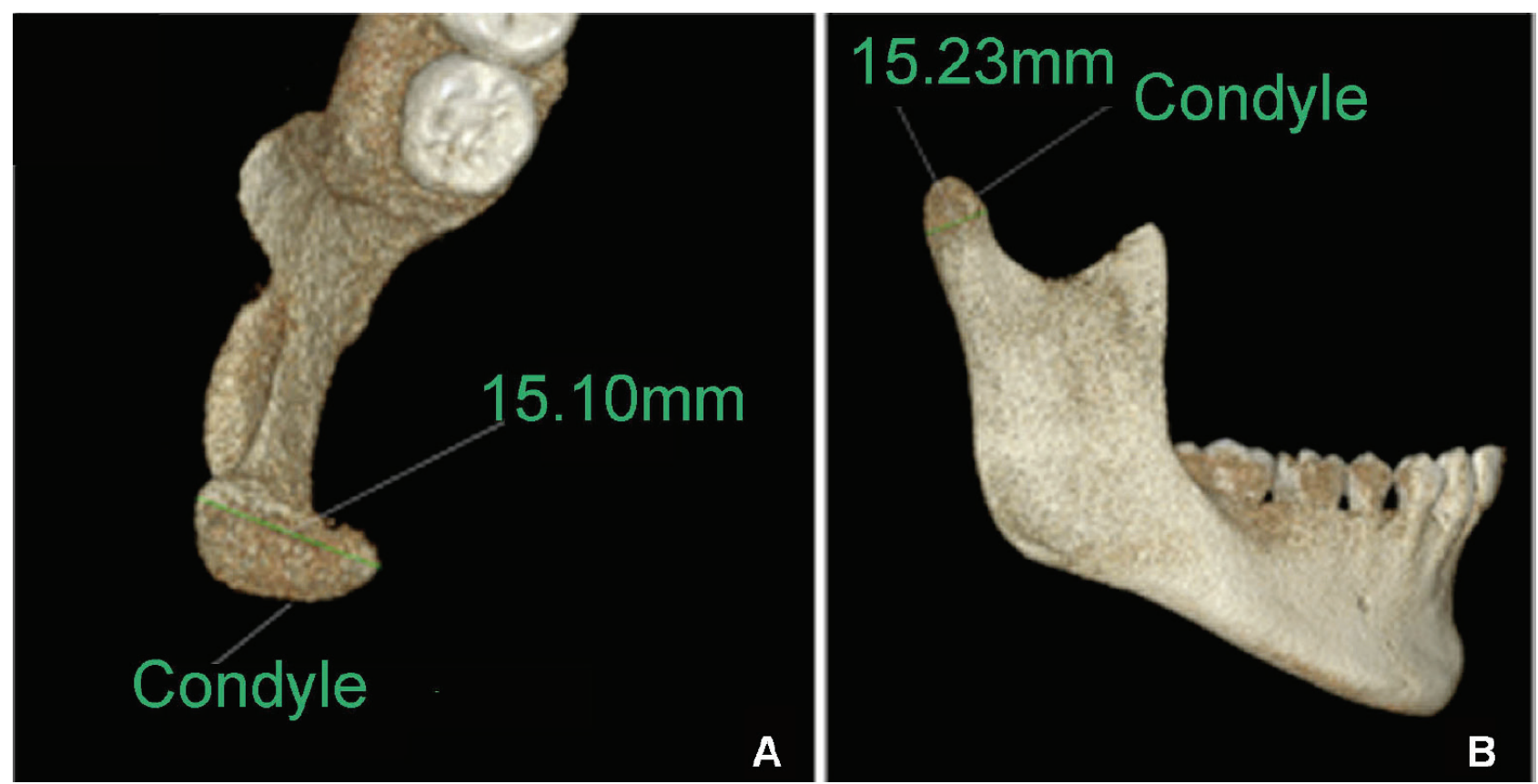

Figure 3 - Examples of $\mathrm{ML}(\mathrm{A})$ and $\mathrm{AP}(\mathrm{B})$ measurements on the virtual 3D models from the OnDemand3D software. 
Table 2 - Standard Deviation Values present in individual samples in $\mathrm{AP}$ and $\mathrm{ML}$ measurements on the left and right sides of the mandibular condyles (MC) of female individuals

\begin{tabular}{|c|c|c|c|c|}
\hline Age & \multicolumn{4}{|c|}{ Standard Deviation } \\
\hline \multirow[t]{2}{*}{ Group } & \multicolumn{4}{|c|}{ For Females } \\
\hline & APRight & APLeft & ML Right & MLLeft \\
\hline $18-30$ & 1.40 & 1.38 & 1.43 & 1.35 \\
\hline $31-40$ & 1.02 & 0.95 & 1.65 & 1.52 \\
\hline $41-50$ & 1.02 & 0.67 & 1.59 & 1.68 \\
\hline $51-60$ & 1.32 & 0.94 & 1.18 & 2.07 \\
\hline 60 or + & 2.02 & 1.97 & 3.12 & 3.09 \\
\hline
\end{tabular}

AP: Anteroposterior measurements of the MC; ML: mediolateral measurements of the MC.

${ }^{*} p \leq 0.05$ (statistically significant).

The coefficient of variation data, shown in Tables 3 and 4, will make use of the classification developed by Gomes [7]. This classification considers coefficients of variation as low when less than $10 \%$, average between 10 and 20\%, high between 20 and $30 \%$, and very high when more than $30 \%$, highlighting that the lower the classification value, the more reliable are the research results.

Table 3 - Values of the coefficient of variation of the male samples

\begin{tabular}{|c|c|c|c|c|}
\hline \multicolumn{2}{|l|}{ Age } & \multicolumn{3}{|c|}{ Coefficient of Variation } \\
\hline \multirow[t]{2}{*}{ Group } & \multicolumn{4}{|c|}{ For Males } \\
\hline & APRight & APLeft & ML Right & MLLeft \\
\hline $18-30$ & $11 \%$ & $11 \%$ & $4 \%$ & $6 \%$ \\
\hline $31-40$ & $9 \%$ & $10 \%$ & $9 \%$ & $12 \%$ \\
\hline $41-50$ & $15 \%$ & $14 \%$ & $6 \%$ & $4 \%$ \\
\hline $51-60$ & $13 \%$ & $9 \%$ & $8 \%$ & $4 \%$ \\
\hline 60 or + & $14 \%$ & $11 \%$ & $8 \%$ & $6 \%$ \\
\hline
\end{tabular}

AP: Anteroposterior measurements of the MC; ML: mediolateral measurements of the MC.

${ }^{*} p \leq 0.05$ (statistically significant).

In the coefficient of variation table of the male sample, it was possible to verify that $55 \%$ of the values were classified as low, with $45 \%$ of the remaining values classified as average.
Table 4 - Values of the coefficient of variation of the female samples

\begin{tabular}{|c|c|c|c|c|}
\hline \multicolumn{2}{|l|}{ Age } & \multicolumn{3}{|c|}{ Coefficient of Variation } \\
\hline \multirow[t]{2}{*}{ Group } & \multicolumn{4}{|c|}{ For Females } \\
\hline & APRight & APLeft & ML Right & MLLeft \\
\hline $18-30$ & $16 \%$ & $16 \%$ & $8 \%$ & $7 \%$ \\
\hline $31-40$ & $12 \%$ & $13 \%$ & $9 \%$ & $8 \%$ \\
\hline $41-50$ & $11 \%$ & $7 \%$ & $8 \%$ & $9 \%$ \\
\hline $51-60$ & $16 \%$ & $11 \%$ & $6 \%$ & $11 \%$ \\
\hline 60 or + & $23 \%$ & $24 \%$ & $17 \%$ & $16 \%$ \\
\hline
\end{tabular}

AP: Anteroposterior measurements of the MC; ML: mediolateral measurements of the MC.

${ }^{*} p \leq 0.05$ (statistically significant).

In the coefficient of variation table of the female sample, it was possible to verify that $40 \%$ of the values are classified as low, $50 \%$ are classified as average, and $10 \%$ as high.

The $t$ test results for independent samples are shown in Table 5.

Table 5 - $p$ values of the AP and ML measurements on the left and right sides of the mandibular condyles (MC) of both males and females, using the t test

\begin{tabular}{lcccc} 
Age & \multicolumn{4}{c}{$\begin{array}{c}\text { p Values (TTEST)-Values of the Comparison } \\
\text { between Males and Females }\end{array}$} \\
\hline Group & APRight & APLeft & MLRight & MLLeft \\
\hline & 0.6758 & 0.6061 & $0.0002^{\star}$ & $0.0001^{\star}$ \\
\hline $18-30$ & 0.1380 & 0.0049 & $0.0007^{\star}$ & $0.0008^{\star}$ \\
\hline $31-40$ & 0.5719 & 0.3513 & $0.0001^{\star}$ & $0.0002^{\star}$ \\
\hline $41-50$ & 0.1249 & 0.3426 & $0.0025^{\star}$ & $0.0148^{\star}$ \\
\hline $51-60$ & 0.5065 & 0.7282 & 0.1088 & 0.2297 \\
\hline 60 or +
\end{tabular}

AP: Anteroposterior measurements of the MC; ML: mediolateral measurements of the MC.

${ }^{*} \mathrm{p} \leq 0.05$ (statistically significant).

Considering the measurements in the anteroposterior direction (AP) of the MCs, only those taken from the left side, for those aged between 31 and 40 years, showed a statistical difference between males and females. 
In relation to the measurements in the mediolateral direction (ML) of the MCs, statistical differences were observed between males and females in all age groups from both sides (right and left), except in the group aged over 60 years, i.e., in individuals below 60 years of age, the ML measurements of the MCs showed significant differences between the sexes.

\section{DISCUSSION}

Identity is the set of characteristics exclusive to one person. Identification is the process in which these characteristics are compared, seeking coincidences between the data previously recorded and those obtained in the present.

Over the years, the techniques for human identification have been enhanced. In addition, there is an increased demand for new methodologies and new resources, seeking to improve the identification procedures [8].

There is also an increase in the use of techniques and processes of human identification, not just for legal reasons, but also psychosocial.

In this respect, this science still faces major challenges, especially in cases of identification in which there is no possibility of directly recognizing the bodies, either because they were found in an advanced state of decomposition (charred bodies, body fragments) or are part of identification processes in cases of massive disasters-natural hazards or those produced directly by human action or influence, which typically result in a large number of fatal victims, making the identification process difficult. For these cases, forensic anthropological techniques generate parameters such as sex, age, and height, among others, for the exclusion of suspects under investigation [9].

When analyzing an intact and fresh corpse, there are no difficulties in identifying the sex, even in the case of a hermaphrodite; the suitable macroscopic and microscopic exams provide satisfactory results for identification. In charred corpses, organs such as the uterus and prostate are sought because they are the ones that resist thermal action, due to their anatomic location in the pelvic girdle, which serves as a protection.

Men and women have different characteristics such as hormonal and skeletal physiology, which correspond to the sexual dimorphism. The skeleton of the individual maintains its characteristics over time, even after death, thus it is considered an important element to sexual differentiation [10].

Daruge et al. stated that the degree of certainty of a sex diagnosis will vary according with the number and nature of the elements analyzed [11]. When only the pelvic girdle is used, there is a $95 \%$ probability of accuracy; when only the cranium is used, there is $92 \%$ accuracy, and when they are analyzed together, it is possible to reach $98 \%$ accuracy [12].

The sex of an unknown individual can be estimated on the basis of morphology (a qualitative analysis) and metric characteristics (a quantitative analysis) of the cranium and mandible. This estimate consists of a metric analysis and visual assessment of the characteristics of the skeleton, cranium, and pelvis. The more assessments that are made, the more reliable will be the result [13].

In terms of the qualitative analyses, there are many morphological characteristics analyzed in sexual dimorphism. The female skull presents itself as more delicate, smaller and lighter, the bone walls are thinner, the surface is smoother, all the crests, roughness, and apophyses of muscular insertions are less prominent, the forehead is lower and narrower, the frontal sinuses are smaller, the glabella has little or no protrusion, as well as the superciliary arches, the frontal and parietal tuberosities are more prominent, the occipital condyles are small, the face is smaller in comparison with the skull, and the maxilla is less bulky [1]. As 
for males, the skull displays characteristics such as a more sloping forehead, more pronounced glabella, more prominent superciliary arches, a more angular frontonasal suture, rounded supraorbital ridges, mastoid apophyses (insertion of the sternocleidomastoid muscle) that are robust, rougher, and more prominent, styloid apophyses that are longer and slightly thicker, a more robust mandible with more evident muscular insertions of the masseter and internal pterygoid, and more robust mandibular condyles $[1,14]$.

França affirms that the bones of the skeleton, especially the skull, mandible, chest, and pelvis are considered for sexual dimorphism. The male skeleton is larger, tougher, and has larger articular extremities. The mandible presents important elements to distinguish the sexes, with significant aspects between the male and female mandibles, taking into consideration that these measurements are even more specific than those of the skull [15].

In males, the mentum is squarer, while in females it is more rounded. In addition, in males the mandible is thicker and the body has more height, the gonial angle between the ramus and the ascending body is less obtuse, the mandibular condyles are larger and the mental region more evident; in females these characteristics are more discreet [3].

As for the quantitative analyses, the estimation of sex through metric analysis is more convenient for it provides mathematical measurements, comparisons, andinterpretations, and is a method easily reproduced that can be standardized, taking into consideration a specific population. In the present study, measurements and pre-established points for metric measurements through the software OnDemand 3D were used to evaluate CBCT exams, which provides the option of visualizing a 3D model after interpreting images in the DICOM format. Measurements between preestablished points were used for the analysis: the distance between the most anterior and the most posterior points of the mandibular condyles and the distance between their lateral and medial poles. These points and measurements were carried out by means of the 3D measuring tool included in the software, which helps to obtain precise measurements in the virtual model. When metric indices are used, the percentage of accuracy (90\%) is greater than when simply analyzing the morphological characteristics of the cranium and mandible (77\%) [12].

The mandible is the strongest and largest bone of the face and its growth is directed through morphological influences [3]. In forensic studies, the mandible is one of the strongest and most durable bones and withstands the processes of degeneration. Therefore, when the mandible is found intact in mortal remains, it plays an important role in determining sex [16].

The temporomandibular joint is classified as the most complex of the human organism. It has the following bone components: mandibular fossa, part of the squamous portion of the temporal bone, and the mandibular condyle.

Aside from its joint function, the mandibular condyle acts as an adaptive growth site, by means of its cartilage.

Morphologically, the mandibular condyle is characterized by a rounded bone projection, featuring an oval upper surface that is biconvex in the axial plane. Mandibular condyles have the medial pole more prominent than the lateral pole. In the present study, it was observed that the mediolateral measurements showed a statistically significant difference between the sexes.

Kharoshan et al. [16] evaluated sexual dimorphism through computed tomography images, considering six mandibular measurements and found that, in three of them, the mean values were greater in males as compared to females. This result corroborates what was found in the present study, because the mediolateral measurements of the mandibular 
condyles were also greater in males as compared to females. Statistical differences were found between the sexes, through mediolateral measurements, except in the age group above 60 years. This variation for the age group above 60 years can be attributed to morphological variations that occur as a function of age, but also of sex, facial pattern, functional load, occlusal force, type of malocclusion, and between the right and left sides. Studies indicate that major changes occur among the elderly due to the onset of their joint degeneration process [17].

Studies in specific populations are important since there are differences between them resulting from factors such as climate, diet, socioeconomic status, and quality of life, which could possibly interfere in the diagnosis [18]. The present study was carried out based on the archives from the Clinic of Radiology at the ICT/UNESP School of Dentistry in São José dos Campos. The institution serves the Paraíba Valley region.

In their study, Kharoshan et al. [16] evaluated the predictors used in sex determination and identified some craniometric measurements with an accuracy of $83.9 \%$ for a group of 330 Egyptian individuals. Iscan and Steyn [19] achieved an accuracy of $84.1 \%$ (cranium and mandible) and $83.7 \%$ (cranium) in the Japanese population. In a population of white South Africans, with an accuracy of $86 \%$ for cranium measurements and $82 \%$ for the mandible, Kieser \& Groenevel [20] obtained 91\% accuracy combining the measurements taken from the two maxillae and two mandibular processes. Gamba et al [11], evaluating sexual indicators in the Brazilian population through CBCT exams, found that some variables, when combined, yielded an accuracy of $95.1 \%$. However, D. Raj [21], in a study with the population of South India, using metric analysis of the mandible and the t-test, concluded that the mandibular condyle and ramus can determine sexual dimorphism.
The present study also used the t-test to evaluate the results in Brazilian patients, through the measurements performed on the CBCT images (mediolateral direction of the condyle) of mandibular condyles and concluded that they can be considered as a predictor for sexual diagnosis.

Panoramic radiography is frequently used, but it does not show good accuracy in studies of small bone changes. However, computed tomography shows measurements more accurately, which also contributes to the diagnosis, planning, and prognosis of different diseases, since it provides a good representation of the joint tissues [22].

For the purpose of the present study, images from CBCT exams were used. The conebeam computed tomography (CBCT) is an examination of high diagnostic accuracy that facilitates the creation of virtual 3D models using high definition systems that make it possible to measure distances and angles [23].

Saini et al. [23], in a study to evaluate sexual dimorphism, observed a less used variable for sexual differentiation within the Indian population-the length of the mandibular ramus. In the same way, but evaluating another variable, the present study analyzed anteroposterior measurements of the mandibular condyle, which did not show values that could be classified as statistically distinguishing between males and females, except on the left side, in the ages between 31 and 40 years of age.

Using CT in the evaluation of sexual dimorphism through the analysis of maxillary sinus, some authors [18] obtained an accuracy of $73.9 \%$ and showed results that could be considered in sexual differentiation in detriment to other methods that were inconclusive. Another study [24] evaluating the foramen magnum and other cranial measurements as determinants of sexual dimorphism, obtained an accuracy of $90.7 \%$ in identifying males and $73.3 \%$ in 
females. The present study, while analyzing mandibular condyles in 3D CBCT images, demonstrated accuracy in sexual differentiation through measurements in the mediolateral direction in all age groups assessed, except above 60 years of age, indicating that the 3D CBCT images are able to accurately produce effective results in anthropometric studies, and can be used as a reliable tool in forensic dentistry, also collaborating to determine sexual dimorphism.

This study led to the verification that the anthropological measurements carried out with 3D CBCT images of the mandibular condyle were able to provide a statistically significant difference between males and females, except in individuals aged 60 years or older.

\section{CONCLUSION}

By the methodology applied in the present study, it can be concluded that the mediolateral measurements of the mandibular condyles, regardless of side, showed statistically significant differences between sexes, in the ages between 18 and 60 years, with a tendency to greater values in males, and may be a determinant factor of sexual dimorphism.

\section{REFERENCES}

1. Franklin D, O'Higgins $\mathrm{P}$, Oxnard CE, Dadour I. Discriminant function sexing of the mandible of Indigenous South Africans. Forensic Sci Int. 2008 Jul 18;179(1):84.e1-5. doi: 10.1016/j.forsciint.2008.03.014

2. Loth SR, Henneberg M, Mandibular ramus flexure. A new morphologic indicator of sexual dimorphism in the human skeleton. Am J Phys Anthropol. 1996 Mar;99(3):473-85.

3. Alves CFP. Estimativa de sexo através de características da mandíbula [tese]. Coimbra: Faculdade de Medicina; 2012.

4. Mozzo P, Procacci C, Tacconi A, Tinazzi MP, Bergamo IA. A new volumetric CT machine for dental imaging based on the conebeam technique: preliminary results. Eur Radiol. 1998;8(9):1558-64.

5. Scarfe WC, Farman AG, Sukovic P. Clinical applications of conebeam computed tomography in dental practice. J Can Dent Assoc. 2006 Feb;72(1):75-80.

6. Pette GA, Norkin FJ, Ganeles J. Incidental findings from a retrospective study of 318 cone beam computed tomography consultation reports. Int J Oral Maxillofac Implants. 2012 MayJun;27(3):595-603.

7. Gomes FP. Curso de Estatística experimental. São Paulo: Nobel; 1990.

8. Terada ASSD, Leite NLP, Silveira TCP, Secchini JM, Guimarães MA, Silva RHA. Identificação humana em odontologia legal por meio de registro fotográfico de sorriso: relato de caso. Rev Odontol UNESP. 2011;40(4):199-202.

9. Cevallos LB, Galvão MF, Scoralick RA. Identificação humana por documentação odontológica: carbonização subsequente à impacto de helicóptero no solo. Rev Conexão SIPAER. 2009;1(1):191-202.

10. Gamba TO. Avaliação do dimorfismo sexual por meio de estudo antropométrico em imagens por tomografia computadorizada de feixe cônico [tese]. Piracicaba: Faculdade de Odontologia da Universidade Estadual de Campinas; 2013.

11. Daruge E, Massini N, Galdino AM. Ensaio de sistematização do ensino da odontologia legal e deontologia odontológica [apostila] Piracicaba: Faculdade de Odontologia da Universidade de Campinas; 1975.

12. Delwing F. Análise do dimorfismo sexual em adultos através de medidas cranianas [tee]. Piracicaba: Faculdade de Odontologia da Universidade Estadual de Campinas; 2013.

13. Almeida Júnior E, Reis FP, Galvão LCC, Rosa HRSP, Costa N. Estimativa do sexo e idade por meio de mensurações cranianas. Rev Bahiana Odontol. 2015;6(2):81-8.

14. Silva RF, Marinho DEA, Botelho TL, Caria PHF, Bérzin F, Júnior ED. Determination of age by dental and wrist joint radiograph analyses: a forensic case report. Arq Odontol. 2008;44(2):45-50.

15. França GV. Medicina Legal. 8. ed. Rio de Janeiro: Guanabara Koogan S.A.; 2008.

16. Kharoshah MA. Sexual dimorphism of the mandible in a modern Egyptian population. J Forensic Leg Med. 2010 May;17(4):213-5. doi: 10.1016/j.jflm.2010.02.005.

17. Uthman AT, Al-Rawi NH, Al-Naaimi AS, Al-Timimi JF. Evaluation of Maxillary Sinus Dimensions in Gender Determination Using Helical CT Scanning. J Forensic Sci. 2011 Mar;56(2):403-8. doi: 10.1111/j.1556-4029.2010.01642.x.

18. Patil KR, Mody RN. Determination of sex by discriminant function analysis and stature by regression analysis: a lateral cephalometric study. Forensic Sci Int. 2005 Jan 29;147(2-3):175-80.

19. Işcan MY. Global forensic anthropology in the 21st century. Forensic Sci Int. 2001 Mar 1;117(1-2):1-6.

20. Kieser JA, Groeneveld HT. Multivariate sexing of the human viscerocranium. J Forensic Odontostomatol. 1986 Dec;4(2):41-6.

21. Raj JD, Ramesh S. Sexual dimorphism in mandibular ramus of south Indian population. Forensic Sci Int. 2010 Apr 15;197(1-3):122. e1-6. doi: 10.1016/j.forsciint.2009.12.052.

22. Neto JV, Estrela C, Bueno MR,Guedes OA, Porto OCL, Pécora JD. Mandibular condyle dimensional changes in subjects from 3 
to 20 years of age using Cone-Beam Computed Tomography: A preliminary study. Dental Press J Orthod. 2010;15(5):172-81.

23. Saini V, Srivastava R, Rai RK, Shamal SN, Singh TB, Tripathi SK. Mandibular ramus: an indicator for sex in fragmentary mandible. J Forensic Sci. 2011 Jan;56 Suppl 1:S13-6. doi: 10.1111/j.15564029.2010.01599.x.
24. Uthman AT, Al-Rawi NH, Al-Naaimi AS, Al-Timimi JF. Evaluation of Maxillary Sinus Dimensions in Gender Determination Using Helical CT Scanning. Dento maxillo facial radiology. UNESP 2012; 41(3): 197-202

\section{Sérgio Lúcio Pereira de Castro Lopes}

(Corresponding address)

Avenida Eng. Francisco José Longo, no 777

Jardim São Dimas - CEP - 12245-000

São José dos Campos, SP

Date submitted: 2017 Apr 07

e-mail: sergio.lopes@fosjc.unesp.br 